\section{EIGHTEENTH INTERNATIONAL PHYSIOLOGICAL CONGRESS}

$\mathrm{T}$

HE Eighteenth International Physiological Congress met at Copenhagen during August 15-18. It was attended by more than 1,200 members who contributed some six hundred communications. To accommodate these numbers was a formidable undertaking, and it was generally felt that the organisers had managed to perform their task smoothly and with admirable efficiency. When opening the Congress, Prof. E. Lundsgaard paid a tribute to the memory of the late Prof. August Krogh, and somewhat diffidently referred to the fact that he himself was presiding only as a substitute; but at the end there was little doubt that he and his helpers, particularly the general secretary, Prof. P. Brandt Rehberg, had excelled themselves in managing the affairs of the Congress, and the gratitude of members was well expressed by the applause with which Prof. Lundsgaard was greeted when he made his final appearance.

There were seven half-day business sessions, four of which were reserved for the presentation of individual short papers, while three were devoted to "General Discussions" of selected problems. To distribute the load, the proceedings were divided into several simultaneous sections : two or three general discussion meetings were held at a time, and individual papers were presented in ten different halls, where each paper had to be read and discussed in fifteen minutes. It is, therefore, impossible for any one person to report on more than a small fraction of the transacted programme. The present writer's main interest lies in the field of nerve and muscle function and the properties of excitable cell membranes, so that he found no time to attend discussions on other matters, and even had to miss some important contributions within his own narrow field of interest.

The session which stands out most in the writer's memory was a discussion on the transport of substances across cell membranes, in which important papers were read by Prof. E. J. Conway, H. H. Ussing, and A. L. Hodgkin and A. F. Huxley. The authors dealt with such different subjects as fermentation in yeast cells, secretion of the gastric mucosa, transport of salt and water across frog skin, and ionic exchange mechanism during the nerve impulse. In spite of the different materials and methods of approach which the authors had chosen, it was interesting to observe that they tended to arrive at a common postulate, namely, the existence in the cell membrane of 'carriersubstances' with specific affinities for certain cations. These substances may be thought of as specific reversible acceptors for potassium, sodium or hydrogen, and it appears that the functional activity of the cell depends upon some form of 'activation' or 'mobilization' of these cation-carriers. But apart from these speculative ideas, a wealth of quantitative information was presented on the movement of individual species of ions across membranes and the extent to which their movement can be controlled by chemical and electrical potential gradients. The audience was particularly impressed by the argument of Hodgkin and Huxley, who supplied precise figures on the movement of sodium and potassium ions across the nerve membrane and concluded that the transfer of these ions is responsible for the electric currents by which nerve impulses are transmitted. In the normal resting nerve cell, no net entry of sodium occurs, in spite of the high inward gradient of its electro-chemical potential. But it appears that a large surge of sodium current, in the direction of this gradient, occurs when the cell membrane is suddenly depolarized. This transient state of rapid sodium transfer is followed by a maintained state of rapid potassium outflux. Hodgkin and Huxley showed that the magnitude and direction of the 'sodium surge' can be controlled, in a theoretically predictable manner, by varying either the potential, or the sodium concentration, gradient across the membrane. On the basis of these findings, it is possible to explain and to reconstruct the events which take place during excitation and the propagation of nerve impulses. The immediate source of energy which is utilized during the transmission of the impulse appears to be the thermal energy of sodium and potassium ions, and active metabolic processes are only called upon slowly to restore and maintain the electro-chemical gradients of the resting cell. During the discussion which followed, Prof. von Muralt paid a generous tribute to the high quality and importance of this work, and the audience gained the same impression during a later session in which A. L. Hodgkin and R. D. Keynes showed some elegant and decisive ways of employing radioactive tracer techniques in a study of ionic movements in nerve axons. As a by-product of this work, direct proof is now available to show that the activity and mobility of potessium ions in the nerve axoplasm is equal, or nearly equal, to that in an aqueous solution.

Among other papers which impressed the writer as new and very important was H. H. Weber's contribution to the discussion on muscle function, in which he showed that the actomyosin-adenosine triphosphate system resembles contracting muscle much more closely, in its mechanical properties, than was previously believed.

There were many other important contributions, both during the discussion meetings, and the sessions in which individual papers were presented. A symposium on the thermodynamics of muscle was opened by Prof. A. V. Hill, followed by A. SzentGyörgyi. The factors affecting cardiac output in man were discussed by A. Cournand, J. McMichael and G. Nylin. Profs. C. H. Best and B. A. Houssay introduced a conference on the hormonal control of fat metabolism, and the properties of the retina were reviewed by Drs. R. Granit, H. J. A. Dartnall and Prof. H. Hartridge. A discussion of the principles of spinal cord activity was introduced by F. Bremer, D. P. C. Lloyd and C. G. Bernhard, and a session concerned with the problems of salt and water excretion was opened by H. W. Smith and E. B. Verney.

In certain sections (for example, those dealing with nerve and muscle function, and with general cell physiology) a good deal of new information was reported which depended upon the recent adaptation of two methods : first, the use of radioactive isotopes in studying the properties of cell surfaces, and secondly, the use of the intracellular recording electrode introduced some years ago by R. W. Gerard.

Inevitably, the papers which have been mentioned here represent only a very narrow selection of the large amount of important material that was presented.

Most members appeared to be very well satisfied with the friendly spirit and the interesting results of this Congress ; but many of them must have pondered over the problems posed by the heavy and increasing 
weight of numbers at such international gatherings. Some further experimentation along the line of 'general discussion meetings' would seem to be required, though many such meetings suffer from the fact that too much time is taken up by long "introductory' papers which leave little opportunity or desire for general discussion afterwards. To achieve a more vivid interchange of ideas and information, it might perhaps be better to have at each session a single introductory review followed by informal discussion. It would also seem that such sessions require some preparatory work by which the organiser approaches individual colleagues in his field to ensure an adequate response.

It is perhaps doubtful whether there remains very much use for sectional sessions in which large numbers of individual papers follow one another, often with little or no connexion and little or no time for questions. If it is felt desirable to retain such sessions, members might at least be discouraged from including papers which have already been published in full. But criticisms such as these are a very minor matter compared with the good that comes from personal contact and the great stimulus that everyone can derive by challenging in private session his scientific friends and opponents.

At the closing session an invitation was received and warmly welcomed to hold the next, the Nineteenth International Physiological Congress, at Montreal in 1953.

\section{CONGRESS OF THE INTERNATIONAL ASSOCIATION FOR THE PROTECTION OF INDUSTRIAL PROPERTY}

$\mathrm{T}$

HE resolutions passed at the Congress of the International Association for the Protection of Industrial Property, held in Paris during June 1950, which have now been published, assume a wider significance in view of the measures being taken in other directions to effect the economic integration of Europe. The Association is an informal body comprising industrialists, patent agents, solicitors and barristers who are directly concerned with questions relating to invéntions, patents, trade marks and copyright. 'The expression "Industrial Property" is a convenient portmanteau phrase for describing commercial rights connected with international trade and industry in these matters.

The conception of a uniform international law in the limited field of industrial property is old. The Association was formed in the seventies of the past century with the object of remedying the insuperable difficulties which then faced a manufacturer or trader in one country in securing protection for his inventions or trade marks in foreign countries.

Prior to 1883 , there were a number of bipartite treaties entered into between various countries which specifically dealt inter alia with the protection of industrial property rights. In 1883, however, an International Convention for the Protection of Industrial Property was concluded in Paris, which laid down certain general principles to be applied by the member States in the manner best suited to their own systems of legislation so as to facilitate inter. national trade and to prevent all kinds of unfair trading. The Convention has been periodically revised, the last revision having been undertaken at a diplomatic conference in London in 1934.

The resolutions passed at the recent Congress of more than four hundred delegates from about forty countries are to be submitted to the Governments of all these countries, as the next revision of the Convention is due to be undertaken at a diplomatic conference in 1951. A summary of the more important resolutions which were passed unanimously is given under the three headings of general resolutions, resolutions dealing with patents, and resolutions dealing with trade marks, as follows.

General Resolutions. The Congress proposed the adoption in the Convention of an Article that "any dispute between two or a number of Convention countries concerning the interpretation or the applieation of the general Convention and of the restricted Conventions which is not settled by negotiation shall be referred to the International Court of Justice [at the Hague] for decision by the latter, unless the countries in question agree upon another method of settlement". In order to prevent the exercise of the power of the veto by one country in suppressing amendments to the Convention, it was resolved that there should be incorporated in the Convention and in the arrangements depending on it the declaration that all amendments approved by at least four-fifths of those voting should be adopted.

Resolutions dealing with Patents. A number of amendments dealing with priority rights in connexion with patents and designs were adopted. Thus, at any time up to the final grant of his patent, an applicant should have the right to divide his application, preserving for his new application the benefit of his original application.

Again, failure to work in a Convention country an invention which is the subject of a patent granted in that country, or the introduction by the patentee into that country of objects manufactured in another Convention country, shall not lead to revocation of the patent. However, in order to prevent abuses which might result from the exercise of the exclusive right conferred by the patent, each Convention country shall be entitled to impose legislative measures providing for the grant of compulsory licences to any qualified applicant. In no case should a compulsory licence be asked for before five years from the date of the application of the patent or three years from the grant, whichever shall be the longer. The grant of a licence should be refused if the patentee can legitimately justify his failure to work the invention. A resolution was adopted proposing a new measure to the effect that patents or certificates of addition shall be freely convertible into principal patents on the application of the patentee.

It is interesting to note that many of these amendments will have the effect of bringing many articles of the Convention more into line with the domestic patent law in Great Britain as set out in the Patent Act of 1949.

Resolution dealing with Trade Marks. The resolutions in regard to trade marks were probably of more immediate and of wider importance to present conditions of international trade. Questions relating to the assignment and licensing of trade marks have caused considerable commercial difficulties. The function of a trade mark is not to indicate ownership, but rather to guarantee that goods bearing a trade mark have certain standards of quality. 'The recognition of free assignability and licensing of trade 